\title{
EFFECT OF SOWING METHODS AND PICKING INTERVALS ON FRESH YIELD AND SEED PRODUCTION OF OKRA (ABELMOSCHUS ESCULENTUS L. )
}

Abdul Basit ${ }^{1}$, Ayesha Zahid ${ }^{1}$, Syed Tanveer Shah ${ }^{1}$, Inayat Ullah ${ }^{2}$, Sana Ullah ${ }^{3 *}$, Muhammad Kashif Nawaz ${ }^{4}$, Muhammad Areeb Khalid ${ }^{1}$, Izhar Ullah ${ }^{5}$, Fawad Ali $^{1}$, Shaukat Ali $^{1}$

\begin{abstract}
To study the effect of various planting beds and picking time on yield of okra, a research study was conducted at Horticulture Research Farm, Malakander, The University of Agriculture Peshawar, Pakistan. Okra seeds of cultivar Swat Green were planted into two different types of sowing methods (ridges and flat beds), and reduced to various number of picking (3, 4, and 5 intervals). The results of the present study revealed that okra plants sown on the ridges recorded maximum germination percentage (96.9\%), fruit weight $(22.41 \mathrm{~g})$, pod length $(14.44 \mathrm{~cm})$, seed pod $^{-1}(48), 100$ seed weight $(6.41 \mathrm{~g})$, seed yield $\left(102.2 \mathrm{~kg} \mathrm{ha}^{-1}\right)$ and fresh yield (0.165 tons ha $\left.{ }^{-1}\right)$. Data regarding number of picking intervals showed that maximum germination percentage $(92.7 \%)$, fruit weight $(20.97 \mathrm{~g})$, pod length $(12.25 \mathrm{~cm})$, seed yield $\left(103.3 \mathrm{~kg} \mathrm{ha}^{-1}\right)$, and seed pod ${ }^{-1}$ (43) were recorded in 3 pickings. Whereas, data for maximum 100 seed weight $(6.6 \mathrm{~g})$ for picking intervals was recorded in 4 pickings and maximum fresh yield ( 0.148 tons ha $^{-1}$ ) in 5 pickings. Infestation of weeds can cause a significant loss in okra yield which needs urgent integrated management. Cyperus rotundus, Echinochloa crusgalli and Digitaria sanguinalis were the main weeds observed during the study against which local farmers used various manual, mechanical and chemical control methods. It is concluded that okra plant sown on ridges and almost 3 picking intervals significantly affected the growth and seed yield hence recommended for the agro climatic condition of Peshawar. Furthermore, Excessive use of chemical herbicides should be avoided to prevent environmental and human health hazards.
\end{abstract}

Keywords: Fresh yield, seed production, okra weeds, picking intervals, sowing methods.

Citation: Basit , A.; A. Zahid; S. T. Shah; I. Ullah; S. Ullah; M. K. Nawaz; M.A. Khalid; I. Ullah; F. Ali; S. Ali. 2021. Effect of Sowing Methods and Picking Intervals on Fresh Yield and Seed Production of Okra (Abelmoschus Esculentus L.). Pak. J. Weed Sci. Res., 27 (3):407418

\footnotetext{
${ }^{1}$ Department of Horticulture, The University of Agriculture, Peshawar-Pakistan

${ }^{2}$ Department of Agricultural Mechanization, The University of Agriculture, Peshawar-Pakistan ${ }^{3}$ Department of Agricultural Leadership, Education and Communication, College of Agricultural and Environmental Sciences, University of Georgia, Athens, GA 30602, USA

${ }^{4}$ Department of Plant Breeding and Genetics, The University of Agriculture Peshawar-Pakistan

${ }^{5}$ Department of Horticulture, Ondukuz Mayis University-Turkey

Corresponding author's email: Sana.Ullah@uga.edu
} 


\section{INTRODUCTION}

With an average yield of 3.10 tons $\mathrm{ha}^{-1}$ okra production is really poor according to a successful growing season. In the situation of low production sometimes, a serious shortage may occur in the commercial marketing of okra (Statistics, 1999). Improper knowledge regarding cultural practices, seed quality, okra fruit and shoot borer diseases, climatic conditions and nutrition may be the possible reasons for low yield and poor production (Kusvuran, 2012; Islam, 1997). Moreover, like others factors such as: temperature, precipitation, moisture content, solar radiation, disease/ pests etc. involves to decrease the yields, no proper weeds management also play key role to reduce the quality and yields of okra and others field crops (Khan et al. 2002a; Khalid et al., 2005). Plants populated densely on intensive highland areas are disposed soil erosion and decline in soil fertility which makes agriculture production unsustainable (Govaerts et al., 2007).

The okra [Abelmoschus esculentus (L.) Moench] vegetable is one of most broadly used species of the Malvaceae family (Bayer and Kubitzki, 2003; Naveed et al., 2009). It is originated from Ethiopia, but nowadays largely grown throughout the world (Khalid et al., 2005). Crops of Malvaceae family are very sensitive to frost and grow well in the summer season. Seeds of okra are sown in plain areas in early April and at the higher elevation by late April. The main problem in the early spring planting is slow and uneven germination of okra seeds (Pandita et al., 2010). According to Baloch (1994), okra is a self-pollinated vegetable crop; however degree of cross pollination may reach up to $4-9 \%$. In Khyber Pukhtun-Khwa, usually it is sown from the mid of March to the mid of April. Egley and Elmore (1987) reported that the main reason for Okra seed germination is its hard seed coat.

Raised beds/ridged soil layers are considered as the most appropriate planting techniques to prevent temporary water log condition. Soil quality and crop production performance can be improved raised beds or ridged soil beds by preventing soil erosion with flowing away debris (Bortolini, 2010). According to Maloney et al. (1993), planting system of raised beds can allow evenly the high susceptible crops to high production of commercial level.

Accumulation of salts on flat soil surface may cause the crusts and hard pans. The crust may be a reason to effect the plant growth which may slow down or stop growth and yielding (Staff, 1954).

Research studies indicated that there is no such or a very little data exist on ridge and flat planting beds to improve okra crop production according to any variation level of field. For that reason, the experiment with considerable needs intended to find out the efficiencies of ridges and flat beds planting system comparatively and to evaluate the influence of picking intensity on growth, yield and seed yield of okra. Additionally, it is intended to know the infestation of weeds in okra fields and its integrated management.

\section{MATERIALS AND METHODS}

\section{Experimental site and plant material}

The present research study was conducted at Horticulture Research Farm, Malakander, The University of Agriculture Peshawar. It is located on the North-West of Peshawar city at $34^{\circ} 0^{\prime} 28^{\prime \prime}$ North, 710 34' 24" East on world map. Peshawar is a subtropical region characterized by severe winter and hot prolonged summer where the maximum temperature reaches up to $47{ }^{\circ} \mathrm{C}$. Seeds of CV. Swat Green were taken from Ornamental Nursery, Department of Horticulture and sown on ridges and flat beds.

\section{Experimental Design}

The experiment was designed using Randomized Complete Block Design with two factors Factorial arrangement. Okra seeds were grown in two different types of 
beds (ridges and flat beds) and the number of pickings were reduced to 3 i.e. data was recorded for 3, 4 and 5 pickings. The experiment was replicated three times with a total number of 18 treatments.

\section{Preparation of field and routine cultural practices}

The field was ploughed and properly leveled to have efficient distribution of irrigation water. Plant to plant distance for ridges was kept $20 \mathrm{~cm}$ and row to row distance $60 \mathrm{~cm}$ as used by Maurya et al. (2013) in their experiment. Seeds of okra cv. Swat Green were sown in the month of April. Before sowing the seeds were kept in water for $24 \mathrm{hrs}$ to make them permeable to the soil nutrients and easy to germinate. Basal dose of NPK at the rate of 120, 90 and 60 was used in the experimental plots. Urea, DAP and SSP were used as a source of nitrogen, phosphorus and potassium. Nitrogen was applied in two splits, one was applied at the time of seed sowing and other after 30 days of sowing. All the cultural practices i.e. irrigation, weeding, hoeing and other cultural practices were kept constant for keeping the field and crop in uniform order. Okra plants were harvested in the late June.

\section{Attributes studied}

The randomly fresh fruit were selected from the plot and their weights were determined by digital balance and at the end their average was taken. The pod length was determined by measuring the pod picked from randomly selected plants and their average was calculated. Fresh pods were picked at regular interval from tagged plants in each treatment and fresh pod yield per plot was recorded in $(g)$ in all pickings and sum of total fresh pod yield was calculated. Then fresh pod yield was converted into tons $\mathrm{ha}^{-1}$. For this purpose, $6-10$ pods plants ${ }^{-1}$ were selected. The seeds were taken out with the help of fruit cutter, counted and their average was calculated. Weight of the seed per plot was recorded for each experimental plot and was converted into seed yield per hectare. Total number of 100 seeds was selected randomly from each treatment and then their average weight in grams was calculated. The data was recorded on the basis of the number of seed germinated out of the total seeds.

\section{Statistical analysis}

The data recorded was arranged according to Randomized Complete Block Design (RCBD) with two factors factorial arrangement (Basit et al., 2019) and subjected to Analysis of Variance (ANOVA) technique (Jan et al., 2009). It was then analyzed using statistical software (Statistix-8 Analytical Software, 2003). In case the data was found significant, least significant difference (LSD) test was applied for means comparison and separation. $\mathrm{P}<0.05$ was considered as significant (Steel, 1997).

\section{RESULTS AND DISCUSSION}

\section{Weed infestation in okra}

Table 1 depicts data regarding various weeds observed in okra field in Malakander area, Peshawar. Weed is a plant which is not sown intentionally and it is found where it is not wanted (Sanaullah, 2018). Nwafor et al. (2010) defined the weed as that plant which is growing out of place and doing more harm as compared to benefits. Therefore, the presence of the weed in crops or where not required can cause side effects on the growth performance as well as productions of the crops by denying them of the plant resources (Gworgwor, 2000; Khan et al. 2002b; Zareen et al., 2017). Weeds infestation in okra is considered as one of the major factors of low yield, due to weeds the losses have been recorded much more than the insect, pest and disease (Khalil and Jan, 2002). Due to no proper management and policy of weeds control, annual average 30-45 \% losses of the total okra production (Usoroh, 1995). Weeds competition varies from crop to crop, depends upon the type of crop, type of weeds, weeding time and management 
practices. The present study results were supported by Santos et al. (2010) where they found that okra was badly affected by the adverse effects of Cyperus rotundus. Similarly, Dada and Fayinminnu (2010) reported that Cynodon dactylon and Eleusine indica were the predominant species among okra weed community.

Table 1. Identification of okra weeds

\begin{tabular}{|l|l|c|c|c|}
\hline $\begin{array}{l}\text { S. } \\
\text { No }\end{array}$ & Botanical name & English name & $\begin{array}{c}\text { Common } \\
\text { name }\end{array}$ & Family \\
\hline 1. & Amaranthus viridis & Smooth pigweed & Churlai/Chalwae & Amaranthaceae \\
\hline 2. & Chenopodium album & $\begin{array}{c}\text { Common } \\
\text { lambsquarter }\end{array}$ & Bathu & Chenopodiaceae \\
\hline 3. & Trianthema portulacastrum & Horse purselane & Itsit/chupatti & Aizoaceae \\
\hline 4. & Cyperus rotundus & Nut grass & Deela or Motha & Cyperaceae \\
\hline 5. & Cynodon dactylon & Bermuda grass & Khabal grass & Poaceae \\
\hline 6. & Eleusine indica & Goose grass & Makra & Poaceae \\
\hline 7. & Echinochloa crusgalli & Barnyard grass & Swank & Poaceae \\
\hline 8. & Digitaria sanguinalis & Crab grass & Takri ghas & Poaceae \\
\hline 9. & Digera arvensis & False amaranth & Tandla & Amaranthaceae \\
& & & & \\
\hline
\end{tabular}

Integrated weed management in okra

Table 2 shows data regarding different weeding methods adopted to avoid the damage of okra crop from its adverse effect. Mostly they are using chemical method of weed control, followed by mechanical and manual control methods in the study area. Control of weeds is really important to avoid crop loss and obtain increased and better yield. Weeds can be a limitation in okra cultivation (Akintoye et al., 2011; Awodoyin and Olubode, 2011; Opadokun and Olorunmaiye, 2019). Weed infestation reduces crop growth and yield. Close okra spacing may reduce and suppress weed infestation (Imoloame and Usman, 2018;
Omovbude and Udensi, 2018). Planting density can affect crop growth and consequently affect weed growth (Ibeawuchi et al., 2005). Studies in the developed countries has shown that using cover crops as an alternative in weed management systems, results in higher yield of crops, since without them; soil deterioration could be most rapid due to high leaching rate of soil nutrients (Akintoye, et al., 2011; Parasuraman, 2000; Silva et al., 2003). Treflan herbicide is applied before sowing; Pendimethalin is widely used pre-emergence, (Barla and Upasani, 2019), while Glyphosate is used as a pre plant for emerged weeds. 
Table 2. Different weeding methods in okra

\begin{tabular}{|l|l|l|}
\hline \multicolumn{2}{|c|}{ Treatments } \\
\hline Chemical weeding & Mechanical weeding/tillage & Manual \\
\hline Pendimethalin & Dutch hoe & Plastic mulch \\
\hline Oxyfluorfen & Harrows & Available weeds mulch \\
\hline Treflan & Sickle & Straw mulch \\
\hline Glyphosate & Mouldboard plough/Disc plough & Cover crops (Sesbania) \\
\hline & Chisel plough & \\
\hline
\end{tabular}

\section{Fruit Length $\mathbf{( c m )}$}

The mean data clearly showed that sowing methods and number of picking significantly affected the fruit length. The interaction between sowing methods and number of pickings was also found significant for fruit length (Figure 1). Maximum fruit length $(14.44 \mathrm{~cm})$ was noted in okra plants sown on ridges while minimum fruit length $(8.06 \mathrm{~cm})$ was noted in okra plants sown on flatbeds. In case of number of pickings okra fruits picked 3 times recorded maximum fruit length $(12.25 \mathrm{~cm})$ followed by fruit length $(10.92$ $\mathrm{cm}$ ) in fruits picked 4 times. The minimum fruit length $(10.8 \mathrm{~cm})$ was noted in fruits picked 5 times. Repeated harvesting may be the cause to increase further fruit length. Flat beds with irrigation may cause soil crust and also the soil properties may degrade while on ridges the soil may not be disturbed with irrigation if flooded. Where ridges plantation may prevent rotting of plant lower parts to enhance uptake of frequent food. These results are in accordance with Osundare (2009), where he found that maximum fruit length recorded in okra plants was influenced by time of picking and planting beds. Vasudevan et al. (2008) also worked with different interval of days for pickings that produced maximum pod length (11.24 $\mathrm{cm}$ ).

\section{Fruit weight (g)}

Fruit weight (g) of okra plant (Figure 1) was significantly affected by types of sowing beds and number of pickings. However, fruit weight (g) was nonsignificantly affected by the interaction between pickings and seed beds. Maximum fruit weight $(20.97 \mathrm{~g})$ was noted in 3 pickings while minimum (19.46 g) was noted in 5 pickings. Mean data for planting beds shows that the ridges gave maximum fruit weight $(22.41 \mathrm{~g})$ while flatbed gave minimum fruit weight (17.30 g) of okra plants. In contrast to our findings, Charles (1977) reposted that early picking interval could cause low fruit weight but late picking could cause problem in marketability due to its over ripen fibrous nature. Therefore, it could be observed that the consumers are always selecting the okra fruit with minimum weight but not over aged ones. This could only be caused in response to quick picking intervals. Short interval picking may have better quality and taste over delayed picking interval. Similar observations were presented by Akanbi et al. (2001), according to their findings the maximum fruit weight recorded in okra plants was affected by beds.

\section{Fresh fruit yield per hectare (tons)}

Green fresh fruit of okra has great importance to the consumer. Its texture, pictorial appearance and length attract the consumer towards itself. Planting beds (Ridges and flatbed) and picking intervals had significant effect on fruit yield tons ha ${ }^{-}$ 1 (Figure 1). Interaction of both planting beds and picking intervals was found nonsignificant. Data analysis showed that 
maximum fresh fruit yield ( 0.148 tons ha $\mathrm{ha}^{-1}$ ) was recorded in 5 pickings followed by 4 pickings $\left(0.147\right.$ tons $\left.\mathrm{ha}^{-1}\right)$ while minimum ( 0.143 tons $\mathrm{ha}^{-1}$ ) was recorded in 3 pickings. It was noted that the crop sown on ridges gave the maximum fruit yield $\left(0.165\right.$ tons $\left.\mathrm{ha}^{-1}\right)$ and the crop sown on flat bed gave the minimum fruit yield $\left(0.127\right.$ tons $\left.\mathrm{ha}^{-1}\right)$. Longer picking interval allowed the pods to have more growth and development before harvesting
(Rashid, 1983). Regarding the flat beds, the reason for low yield might be due to the non or less availability of nutrients as flooded by flood irrigation from the soil surface. Similar results were found by Mishra (1996), where he studied that fruit yield was increased on ridges in cucumber. Similarly, Saha et al. (1989) also reported the same results in their research study.
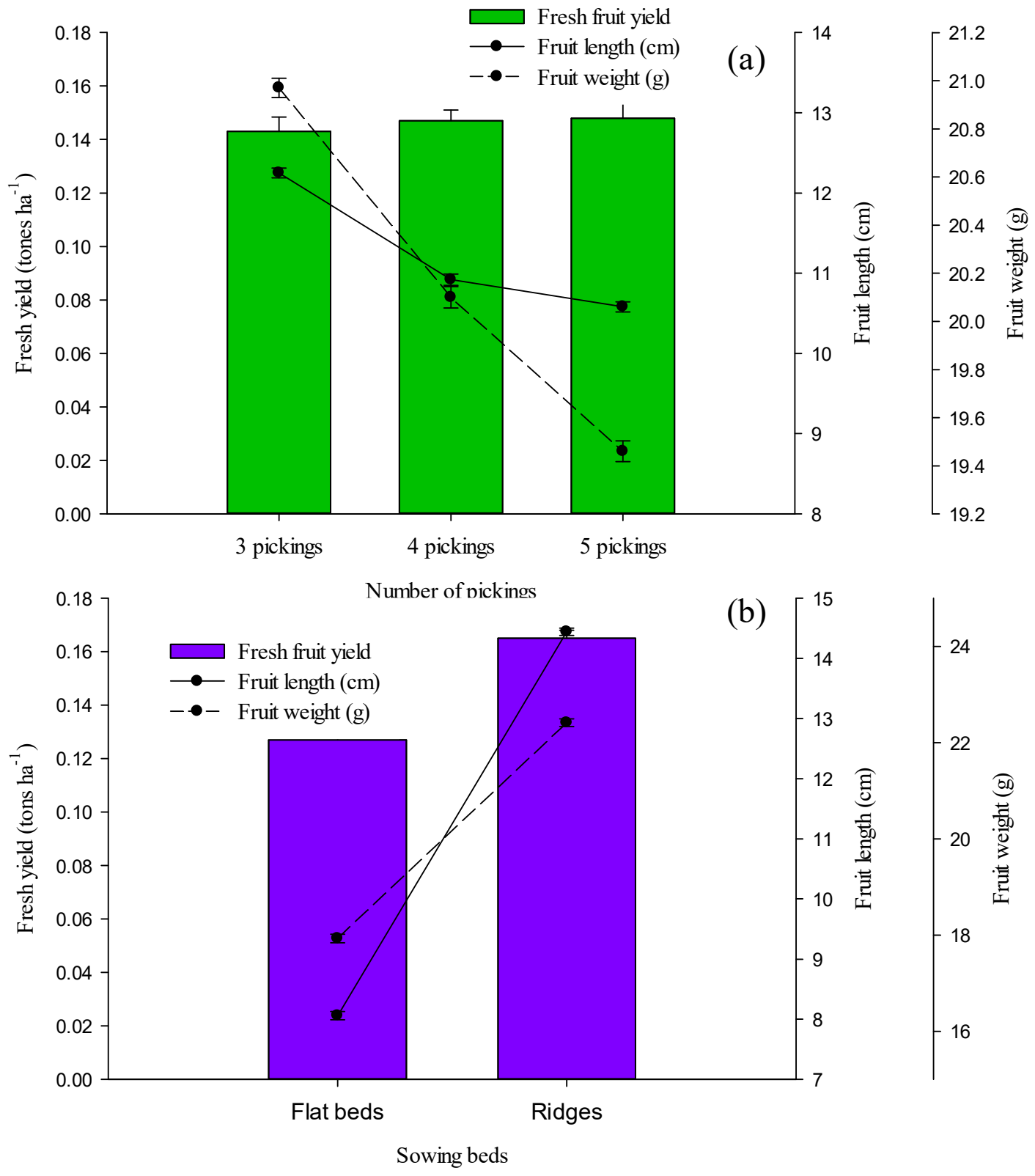

Figure 1: Fruit length, fruit weight and fresh yield of okra as affected by (a) number of pickings and (b) sowing methods 


\section{Number of seed pod $^{-1}$}

It is evident from the mean data (Figure 2 ) that ridges and flatbed had a significant effect on seeds per pod and the interaction also showed significant effect on picking and seed beds (Figure 2). Okra plants grown on ridges gave maximum number (48) of seeds per pod, while okra plantation on flatbed gave minimum number (37) of seeds per pod. However the pickings also had significant effect on seeds per pod. Okra plants picked 3 times had maximum number of seeds per pod (43) whereas 4 and 5 pickings had minimum (42). The results of Sajjan et al. (2002) are quite similar in confirmation to the above results. According to them the difference in beds significantly affected number of seeds per pod. They also concluded that variation in the number of seeds pod $^{-1}$ might be because of double picking in plants kept under stress followed by 1 picking and no picking.

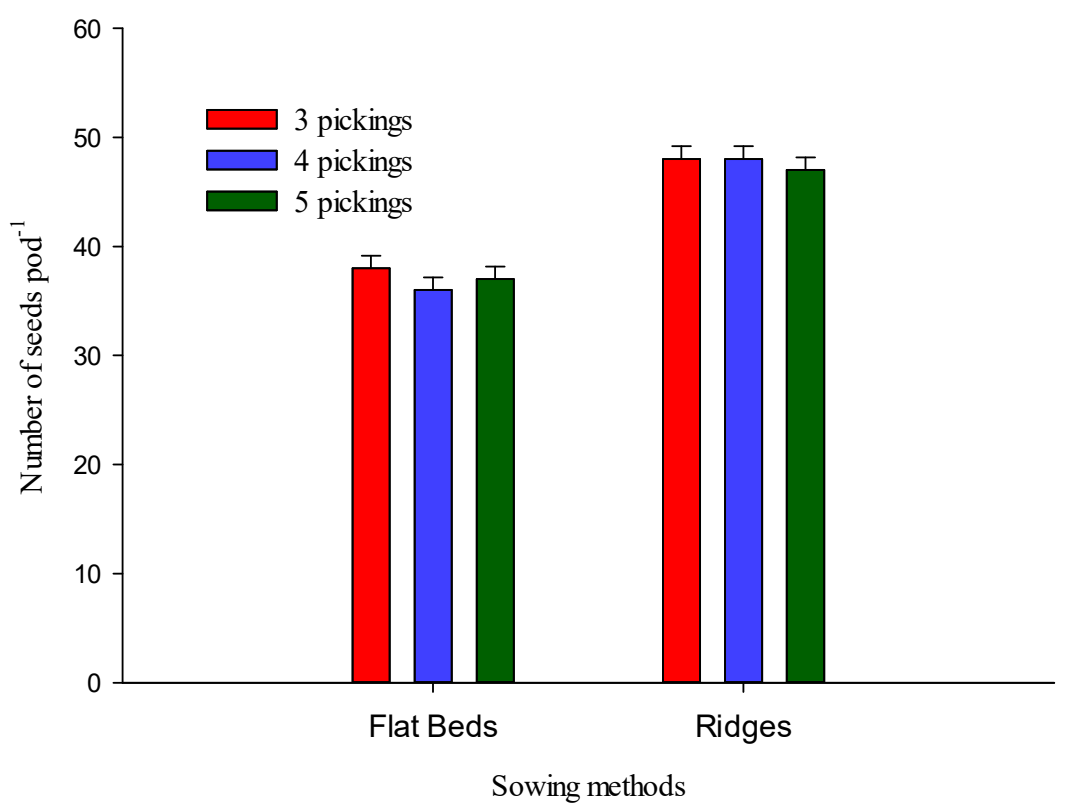

Figure 2: Number of seeds pod $^{-1}$ of okra as affected by the interactive effect of sowing methods and number of pickings of okra.

\section{Seed yield $\left(\mathrm{kg} \mathrm{ha}^{-1}\right)$}

Seed yield is the desired component of okra crop. Data representing the effect of seed yield $\left(\mathrm{kg} \mathrm{ha}^{-1}\right)$ of okra was influenced significantly by different planting beds and number of pickings (Figure 3). And the interaction had non-significant effect on picking and seed beds. Seed yield recorded for okra was maximum (102.2 $\mathrm{kg} \mathrm{ha}{ }^{-1}$ ) on ridges whereas it was minimum (61.9 kg ha-1) on flatbed. However, 3 pickings had maximum seed yield $\left(103.3 \mathrm{~kg} \mathrm{ha}{ }^{-1}\right)$ followed by 4 pickings (73.9 kg ha-1) while minimum $\left(68.9 \mathrm{~kg} \mathrm{ha}^{-1}\right)$ was found in 5 pickings. Number of picking is a desirable character in okra production and directly related to the yield of okra. Similarly, Singh et al. (1995) studied the effect of green fruits harvested at 2 days interval $(0,1,2,3$ or 4 pickings) on the seed production of okra cultivar Punjab-7. They found that highest seed yield was noted for 2 pickings ( 7.42 q/ha in 1993 and $7.35 \mathrm{q} /$ ha in 1994) on successful trials planted in 1993 and 1994. 


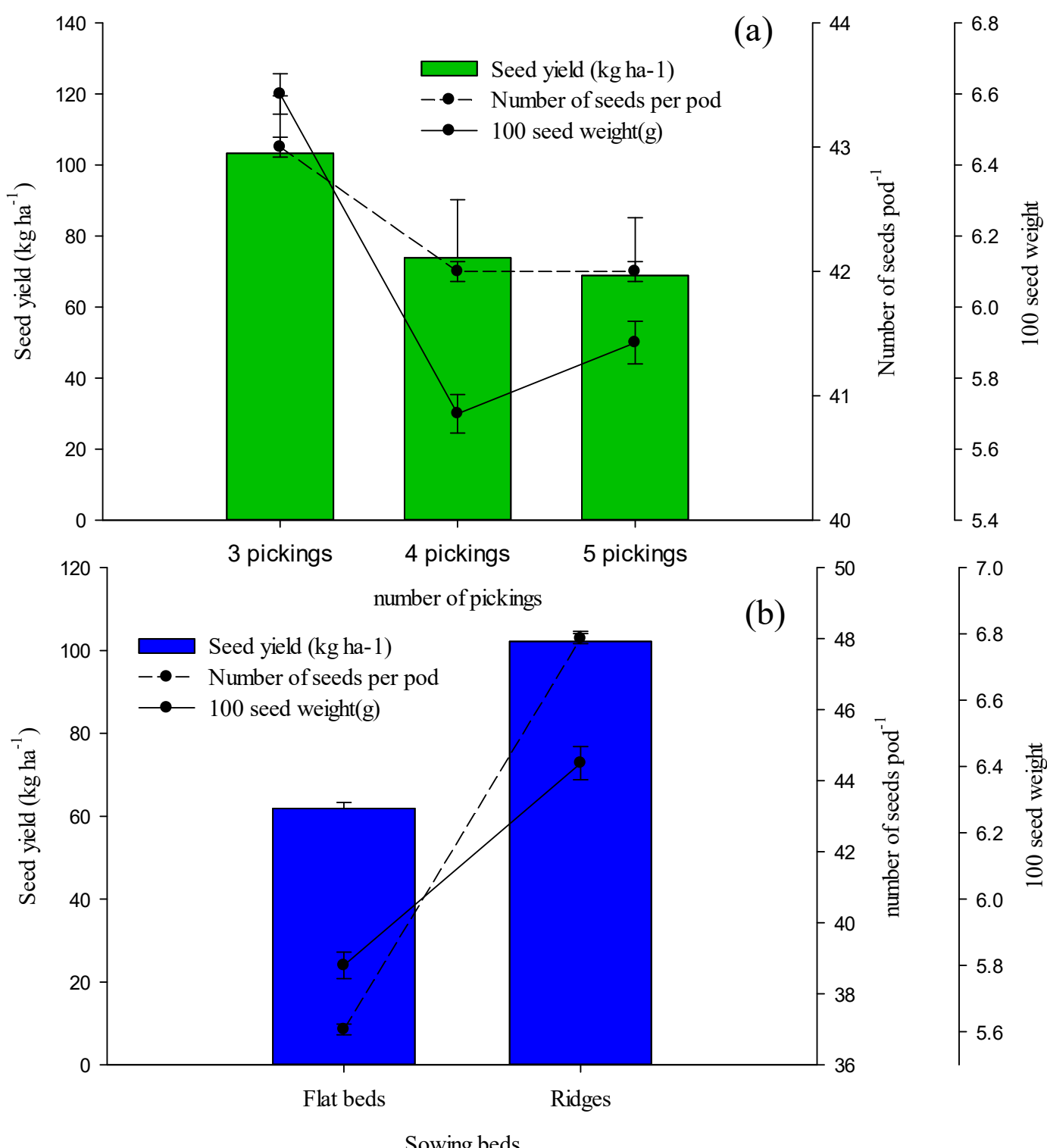

Figure 3: Number of seeds pod ${ }^{-1}, 100$ seed weight and seed yield of okra as
affected by (a) number of pickings and (b) sowing methods

\section{0 seed weight $(\mathrm{g})$}

The data pertaining to 100 seed weight (g) showed significant effect on number of pickings and planting beds (Figure 3). However, interaction of number of pickings and seed beds had no significant effect on 100 seed weight. Maximum 100 seed weight $(6.6 \mathrm{~g})$ was noted in 3 pickings followed by 4 pickings $(5.9 \mathrm{~g})$ while minimum $(5.7 \mathrm{~g})$ was observed in 4 pickings. Where the ridges gave maximum 100 seed weight $(6.3 \mathrm{~g})$, while flatbed gave minimum $(5.3 \mathrm{~g})$. The increased seed weight might be due to the mobility of photosynthates in the leaves that carries food to the fruit. This might be due to availability of nutrient which were not flooded with irrigation or due to frequent pickings. Grewal et al. (1972) studied seed production of okra Cv. Pusa sawani as effected spacing and picking green 
pods. They observed that 100 seed weight was decreased with wider spacing and increased number of pickings. It was noted that 2 pickings of green pods had no severe effect on seed yield and was profitable.

\section{Germination percentage}

Figure 4 showed significant effect of sowing methods on germination percentage of seeds of okra. Germination percentage of okra seeds on ridges was maximum (96.9\%) and it was minimum $(86.9 \%)$ on flatbed. However, 3 pickings gave maximum percentage (92.7\%) followed by the 4 pickings (92\%) and minimum ( $91 \%$ ) was noted in 5 pickings. The germination percentage of seeds picked from ridges might be due to the nutrients and water holding capacity of ridges which are helpful for soil quality; where consecutive picking interval may cause the frequent uptake of quality food nutrients. Similarly, Yuan et al. (2005) observed that germination percentage was maximum in ridges of summer maize while it was decreased in flatbed.

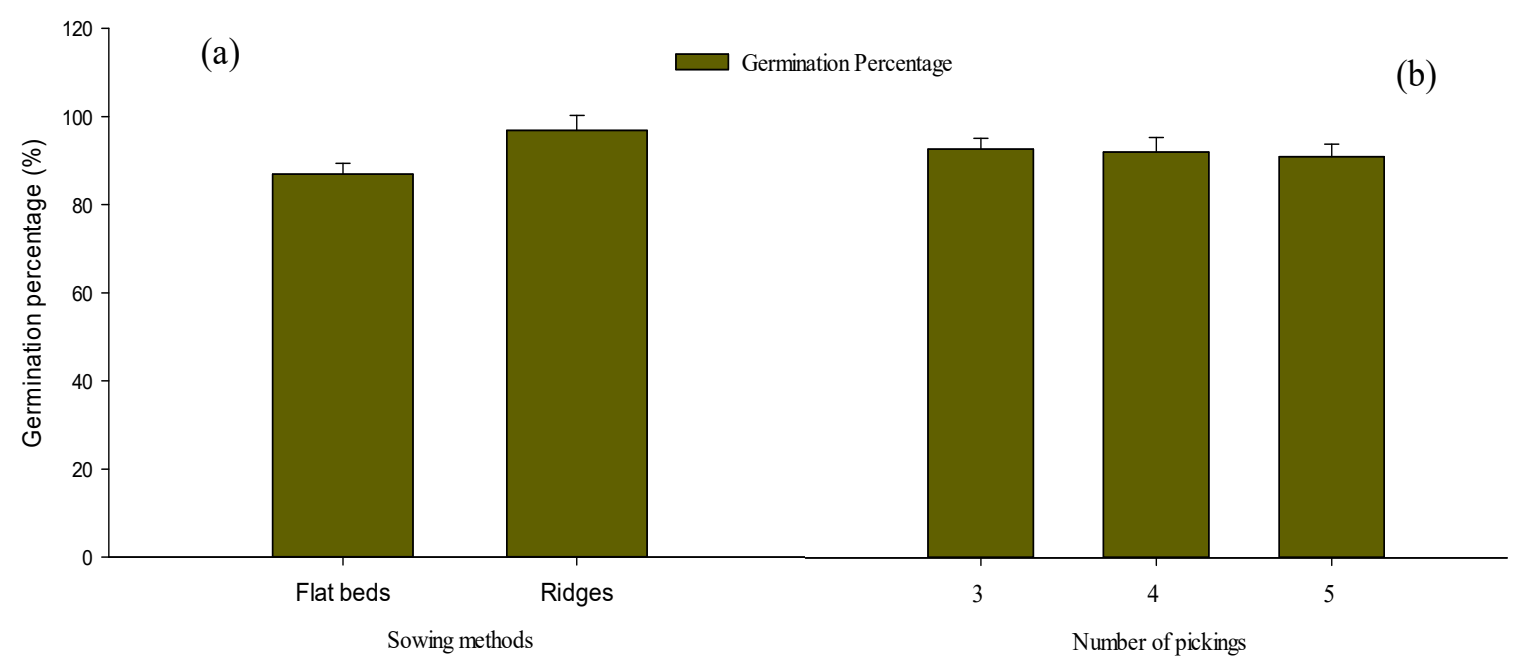

Figure 4: Germination percentage of okra as affected by different sowing methods

\section{CONCLUSION RECOMMENDATIONS}

It was concluded from the above results that the number of pickings and different planting beds has significantly influenced growth and yield components of okra plants. Where maximum number of pods plant $^{-1}$, average pod length $(\mathrm{cm})$ and fresh pod yield (tons ha-1) was recorded in plants on 3 pickings and which were grown on Ridges. Hence, okra crop planted on ridges with three pickings could be recommended for the farmers of Khyber Pakhtunkhwa to get better growth, fresh yield and seed yield. Majority of the farmers in Pakistan rely on chemical weed control methods which is not good for environmental and human health concerns, therefore, it is suggested to lessen its use and adopt integrated management techniques. 


\section{REFERENCES}

Akanbi, W.B., J.A. Adediran, A.O. Togun and R.A. Soul. 2001. Effect of organic base fertilizer on the growth, yield and storage life of tomato (Lycopersicon esculoutum Mill). Biosci. Res. Comm., 12(4):14-18.

Akintoye, H.A., A.G. Adebayo and O.O. Aina. 2011. Growth and yield response of okra intercropped with live mulch. Agric. Res., 5:146-153.

Awodoyin, R.O. and O.S. Olubode. 2011. Assessment of critical period of weed interference in okra feld in Ibadan, a rainforest Savanna transition eco-zone of Nigeria. Acta Hortic., 911: 99-111.

Baloch, A.F. 1994. Vegetable Crops: Horticulture. National Book Foundation, Islamabad, pp. 529-531.

Barla, S. and R.R Upasani. 2019. Economic feasibility of weed management in okra [Abelmoschus esculentus (L.) Moench]. International J. of Chem. Studies. 6: 333-335.

Basit, A., S. Ayaz, A. Rab I. Ullah, S.T. Shah, I. Ahmad, I. Ullah and M.A. Khalid. 2019. Effect of stevia (Stevia Rebaudiana L.) leaf extract on the quality and shelf life of lemon (Citrus limon L.). Pure Appl. Biol., 8(2): 1456-1468.

Bayer, C. and K. Kubitzki. 2003. The families and genera of vascular plants. In: Malvaceae, (K. Kubitzki Ed.). pp. 225-311.

Bortolini, L. 2010. Effect of Seed-Beds on the Cultivation of Radicchio (Cichorium intybus L., Rubifolium Group). Contemporary Eng. Sci., 9(21): 997-1014.

Charles, W.B. 1977. "Okra Growing." University of the West Indies. Extension Bulletin, University of the West Indies. 28: 9.
Dada, O.A. and O.O. Fayinminnu. 2010. Period of weed control in okra [Abelmoschus esculentus (L.) Moench] as influenced by varying rates of cattle dung and weeding regimes. Notulae Botanicae Horti. Agrobotanici Cluj-Napoca. 38(1): 149-154.

Egley, G.H. and C.D. Elmore. 1987. Germination and the potential persistence of weedy and domestic okra (Abelmoschus esculentus) seeds. Weed Sci., pp. 45-51.

Govaerts, B, K.D. Sayre, K. Lichter, L. Dendooven and J. Deckers. 2007. Influencing of permanent raised bed planting and residue management on physical and chemical soil quality in rain fed maize/wheat system. 291(12): 39-54.

Grewal, B.S., K.S. Nandpuri and J.C. Kumar. 1972. Effect of date of sowing, spacing and picking of green pods on seed production of okra (Abelmoschus esculentus L. moench). Punjab Horti. J., pp. 3439.

Gworgwor, N.A. 2000. Effects of intercropping sorghum with groundnut in semi-arid zone of Borno State. Nigerian J. Weed Sci., 13: 6369.

Ibeawuchi, I.I., J.C. Obiefuna and M.C. Ofoh. 2005. Effects of row spacing on yield and yield components of okra and mixture groundnut. J. Agron., 4(4):304-307.

Imoloame, E.O. and M. Usman. 2018. Weed biomass and productivity of okra as influenced by spacing and pendimethalin-based weed management. J. Agric. Sci., 63(4):379-398.

Islam, M.S. 1997. Off-season performance of okra for vegetable and seed production. M.Sc. Thesis, Institute of Postgraduate Studies in Agriculture, Salna, Gazipur, Bangladesh. 
Jan, M.T., P. Shah, P.A. Hollington, M.J. Khan and Q. Shohail. 2009. Agriculture Research: Design and Analysis. 1st Ed. Dept. of Agronomy, The Uni. of Agriculture, Peshawar, Pakistan.

Khalid, U., E. Ahmad and U.K. Muhammad. 2005. Integrated weed management in okra. Pak. J. Weed Sci. Res., 11(1-2): 55-60.

Khalil, I.A. and A. Jan. 2002. Cropping Technology. Published by National Book Foundation Islamabad Pak. pp. 130.

Khan, M.A., G. Hassan, W.A. Shah and M. $Z$. Afridi. 2002a. Duration effect of weed competition on the yield and yield components of wheat. Sarhad J. Agric., 18(3): 335-337.

Khan, M.A., K.B. Marwat, G. Hassan and W.A. Shah. 2002b. Effect of different weed free periods on the growth and yield of wheat. Pak. J. Agri., Agril. Eng. Vet. Sci., 18(1-2):30-33.

Kusvuran, S. 2012. Influence of drought stress on growth, ion accumulation and antioxidative enzymes in okra genotypes. Int. J. Agric. Biol., 14:401-406.

Maloney, K.E., W.F. Wilcox and J.C. Sanford. 1993. Raised Beds and Metalaxyl for Controlling Phytophthora Root Rot of Raspberry Cornell University, New York State Agricultural Experiment Station, Geneva, NY 14456. 28(11): 11061108 .

Maurya, R.P., J.A. Bailey and A. Chandler. 2013. Impact of Plant Spacing and Picking Interval on the Growth, Fruit Quality and Yield of Okra (Abelmoschus esculentus (L.) Moench). Ameri. J. Agri. \& Forestry. 1(4): 48-54.

Mishra, S.N. 1996. Multivariate analysis of genetic divergence in cucumber. Indian J. Agri. Sci., 66 (8): 502-503.
Naveed, A., A.A. Khan and I.A. Khan. 2009. Generation mean analysis of water stress tolerance in okra. Pak. J. Bot., 41: 195-205.

Nwafor, O.E., S.O. Adepoju, A.A. Mba, M.C. Okonkwo, M. Emefiene and K. Aminu. 2010. Proceedings of $24^{\text {th }}$ Annual National Conference of Farm Management Association of Nigeria (FAMAN) held at Adamawa State University Mubi between $11-14^{\text {th }}$ October.

Omovbude, S. and E.A. Udensi. 2018. Response of okra [Abelmoschus esculentus (L.) Moench] and weeds to plant spacing and weeding regime in a humid forest agro-ecology of South-Eastern Nigeria. J. Appl. Life Sci. Int., 18(3):1-13.

Opadokun, W.O. and K.S. Olorunmaiye. 2019. Effects of weed density and distance on the growth and yield of two okra varieties. Notulae Sci. Biol., 11(3):429-435.

Osundare, B. 2009. Effects of time of nitrogen application and frequency of weeding on the performance of okra (Abelmoschus esculentus L.) in southwestern Nigeria. Global J. Agri. Sci., 8(1): 11-15.

Pandita, V.K, A. Anand, S. Nagarajan, R. Seth and S.N. Sinha. 2010. Solid matrix priming improves seed emergence and crop performance in okra. Seed Sci. \& Technol., 38(3): 665-674.

Parasuraman, P. 2000. Weed management in rain fed cowpea (Vigna unguiculata) and greengram (Phaseolus radiatus) under North West Agro climatic zone of Tamil Nadu. Indian J. Agrn., 45: 732-736.

Rashid, M.M. 1983. Bangladesher Shabji, Begum Sahela Rashid. 1st Edn., Bangladesh Agricultural Research Institute, Joydebpur, Bangladesh. pp. 185. 
Saha, P.K., D.K. Aditya and A.F.M. Sharfuddin. 1989. Effects of plant spacing and picking interval on the growth and yield of okra cv. Pusa sawani. Bangladesh Horti., 17: 1014

Sajjan, A.S., M. Shekaragoud and V.P. Badanur. 2002. Influence of apical pinching and fruit picking on growth and seed yield in Okra. Karnataka J. Agri. Sci., 15(2): 367-372.

Sanaullah. 2018. An analysis of the adoption of improved farming practices of maize in Bajaur Agency. M.Sc (Hons) Thesis, submitted to The Department of Agricultural Extension Education and Communication, The University of Agriculture Peshawar, Pakistan. Pp. 38.

Santos, J.B, T.P. Silveira, P.S. Coelho, O.G. Costa, P.M. Matta, M.B. Silva, A.P. Drumond Neto. 2010. Interferência de plantas daninhas na cultura do quiabo. Planta Daninha. 28(2):255-262.

Silva, J.B.F., J.B. Pitombeira, R.F. Nunes, J.L.N. Pinho. 2003. Weed control in cowpea under no till system. Planta Daninha. 21: 151-157.

Singh, R., J.S. Kanwar and R. Singh. 1995. Effect of green fruit pickings on plant growth, seed yield and seed quality of okra (Abelmoschus esculentus (L.) Moench). Punjab vegetable grower. 30: 54-57.

Staff, S.L. 1954. "Diagnosis and Improvement of Saline and Alkali Soils," Agriculture Handbook No. 60, USDA, US Government Printing Office, Washington, D. C.

Statistics, B.B. 1999. Yearbook of agricultural statistics of Bangladesh. Ministry of Planning, Dhaka, Government of the People's Republic of Bangladesh, pp. 96.

Statistix-8 Analytical Software. 2003. Statistix-8 User's Manual.
Tallahassee, Florida: Analy. Software. ISBN 1-881789-06-3.

Steel, R. 1997. Analysis of variance I: The one-way classification. Principles and Procedures of Statistics A Biometrical Approach. pp. 139-203.

Usoroh, N.J. 1995. Effects weed control strategies for fruit and vegetable production in Nigeria. Paper presented at National workshop on farming system for sustainable production of fruits and vegetable held at National Horticultural research institute Ibadan.

Vasudevan, S.N., J.S. Sudarshan, M.B. Kurdikeri and P.R. Dharmatti. 2008. Influence of pinching of apical bud and chemical sprays on seed yield and quality of fenugreek. Karnataka J. Agri. Sci., 21 (1): 26-29.

Yuan, H.M., X.L. Wang, J.C. Sun, D.S. Chen and G.Z. Zhao. 2005. Study on wheat bed planting mode for water saving and high yield in the yellow river irrigation of Ningxia region. Water Savi. Irrig., 6: 5-7.

Zareen, S., S. Khan, I. Ahmad, M. Haroon, I. Khan and I. Ullah. 2017. Effect of various weed infested periods on okra under agro-climatic conditions of DI Khan, Pakistan. Pak. J. Weed Sci. Res., 23(1):93. 